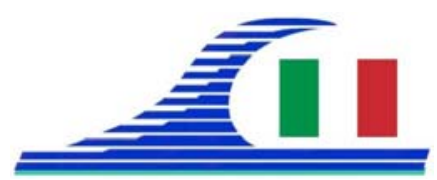

Conférence Méditerranéenne Côtière et Maritime EDITION 3, FERRARA, ITALIA (2015)

Coastal and Maritime Mediterranean Conference

Disponible en ligne - http://www.paralia.fr - Available online

\title{
Recent evolution of the Vendicari barrier system, Southern Sicily, Italy
}

\section{Paolo CIAVOLA ${ }^{1}$, Marco BIRRITTIERI ${ }^{1}$}

\author{
1. Dipartimento di Fisica e Scienze della Terra, Università di Ferrara, Via Saragat 1, \\ 44122 Ferrara, Italy. \\ cvp@unife.it
}

\begin{abstract}
:
The current paper describes the 50-year evolution of coastal lakes (Vendicari) in southern Sicily, separated from the sea by a barrier system, divided into two distinct cells by the presence of a rocky island nearshore. Shoreline and dune foot change were studied by means of the DSAS tool of ArcGis, interpreting aerial flights spanning from 1955 to 2007. The morphology of the dune system was mapped during a program of field validation in 2004. The study identified the evidence of sand mining occurred on the dunes in the 1970s, leaving a scar on the dune system still not healed. An analysis of changes in beach width identified a different behaviour of the northern and southern cells. The northern one in the last 50 years has experienced a progressive reduction at a rate of up to $1 \mathrm{~m} /$ year. On the northern hand the southern cell increased beach width at a rate of $0.5 \mathrm{~m}$. Projection of coastal retreat up to 2050 shows that beach retreat will eventually threaten the integrity of the back-barrier environments of the lakes.
\end{abstract}

Keywords: Coastal wetlands, Shoreline migration, Man-made sand excavation, Dune overwash.

\section{Introduction}

Traditionally coastal wetlands in Italy were used for fishing and salt production but because of malaria and demand for agricultural land large reclamation works were undertaken by the Fascist Government before WWII and continued in the post-war period. After the cessation of land reclamation, coastal wetlands have been subjected to attacks and alterations sometimes reckless and unplanned. Even the extensive system of wetlands along the coasts of the southern Ionian Sea, has been the subject of intensive land reclamation that has caused a drastic reduction.

The coastal lakes of Vendicari (locally called Pantani) are those that in Sicily suffered minor manipulation by man, retaining good environmental integrity, which allows to include them in the list of the most representative for this type of environments on the Italian territory. The inclusion in 1989 in the list of wetlands of international interest established by the Ramsar Convention was the clear recognition of the enormous importance that the marshes of Vendicari have. 
Côtes méditerranéennes menacées :

Risques et défis dans le contexte du changement climatique

\section{Area description}

The area of Vendicari is located in south-eastern Sicily, near the city of Noto, to the south of Syracuse (Fig.1). It is characterized by a flat and uniform coastal morphology, gently sloping towards the sea, crossed by two major torrential incisions, the Saia Roveto e Saia Scirbia. The four coastal lakes that constitute the system extend parallel to the coast for a length of about $6 \mathrm{~km}$, closed at either ends by rocky headlands located at Torre Sveva and Cittadella dei Maccari. The lakes are separated from the open sea by a sandy coastal barrier, with a well-developed dune ridge. According to a recent paper by GRACIA et al. (2014), the lakes have a karstic origin and were originated as a part of a $6 \mathrm{~km}$ long polje during the Late Pleistocene sea level lowstand. At Punta d'Isola because of the opposite directions of the nearshore currents the shoreline forms a cusp. Until the 1950s Punta d'Isola was connected to the Isle of Vendicari through a tombolo, now completely eroded (Fig. 1).
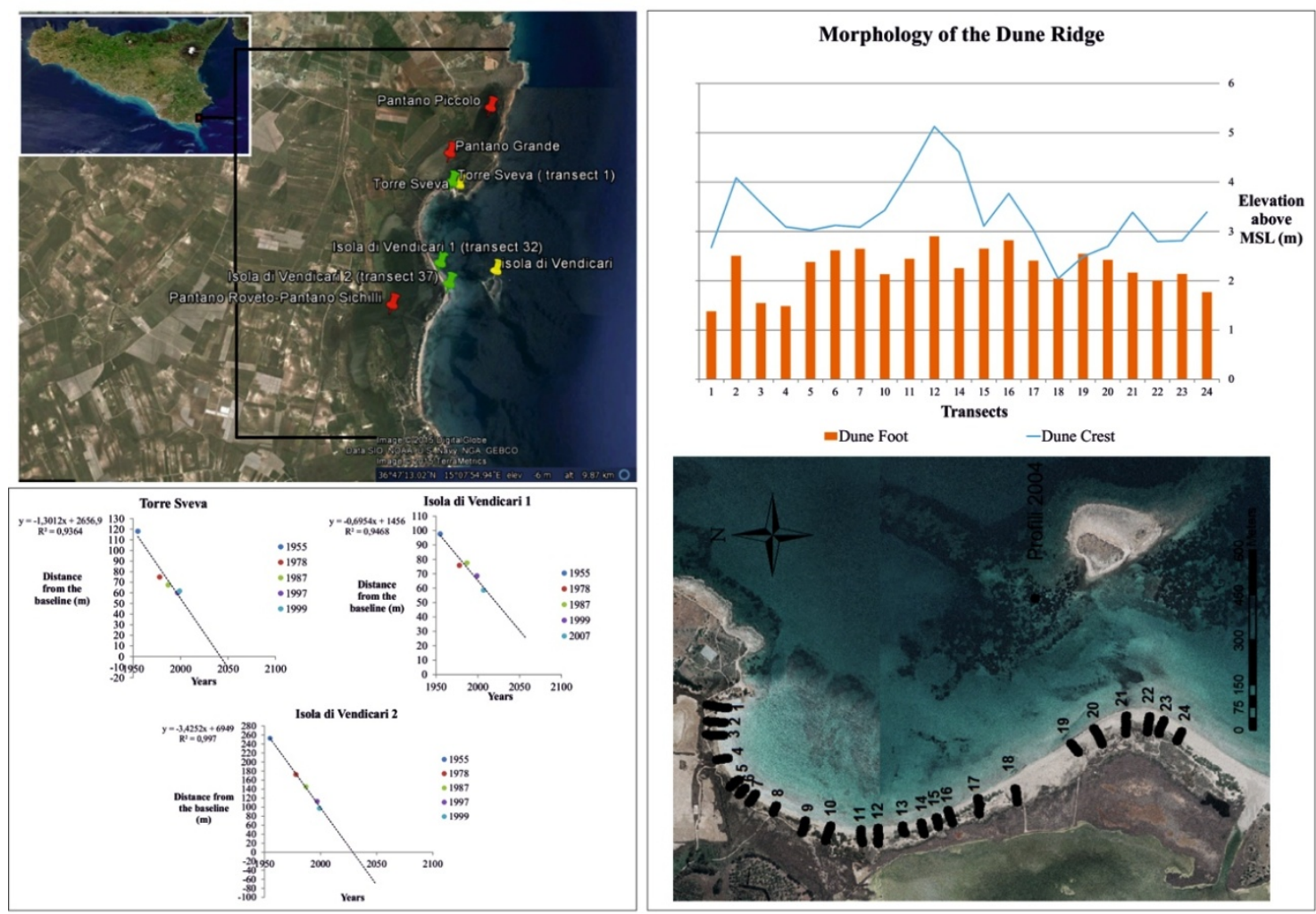

Figure 1. Location of the study area, characteristics of dune belt (top right panel), location of surveyed topographic profiles (bottom right panel) and trends in shoreline erosion obtained from the aerial photographs.

According to measurements of ISPRA (APAT, 2006) at the Catania buoy for the period 1989-2006, the dominant wave direction is from the East (30.56\%), followed by SE (21.49\%) and NE (20.59\%). The highest waves have directions are comprised between 
Mediterranean coasts at threat:

Hazards and challenges in the context of climate variability

$75^{\circ} \mathrm{N}$ e $120^{\circ} \mathrm{N}$ and can reach maximum heights of $6.3 \mathrm{~m}$. According to APAT (2006) the maximum wave energy flux approaches the coast with directions limited between $75^{\circ} \mathrm{N}$ and $105^{\circ} \mathrm{N}$.

Mobile dunes, on which the typical Mediterranean vegetation flourishes, occupy the landward boundary of the barrier system. The dune belt in the northern part of the bay is completely immobilized by a fence, built by the Authorities that manage the nature reserve to limit the indiscriminate access to the beach through the dunes and restore vegetation. Near Punta d'Isola in the 1970s about 3 hectares of dunes were destroyed from the opening of a sand quarry. More than thirty years were not enough to heal this wound, for which the Authorities made interventions with windbreak barriers to promote the restoration of the dune-destroyed belt. Finally stabilized high dunes, characterize the barrier in the southern part of the bay with a high elevation above MSL, characterized by the presence of shrub vegetation, including Juniperus oxycedrus L. ssp. Macrocarpa as the most abundant species.

\section{Methods}

The post WWII evolution of the system of coastal lakes was studied by photointerpretation of flights conducted in 1955 (1:34000), 1978 (1:18000), 1987 (1:10000), 1997 (1:20000), 1999 (1:10000) and 2007 (1:20000). While the most recent flights are in colour and available in digital format, older flights are often in Black\&White and available in paper format. All images were georeferenced to the Gauss-Boaga Italian coordinate system. Geomorphological features like the pond margins, streams, dune crest, dune base and shoreline were mapped. The latter was identified as wet/dry mark according to the indications of MOORE (2000), as this corresponds to the daily highest tidal level (DOLAN et al., 1980). To notice that in any case, the average tidal range in the area is smaller than $20 \mathrm{~cm}$ (TSIMPLIS, 1994), therefore this tidally-induced errors are small. The shoreline change across datasets was estimated with the ArcGis DSAS Tool (THIELER et al., 2009) using both the EPR and LRR method. The same approach was used to study changes in the position of the dune foot. Beach width was calculated using the SCE (Shoreline Change Envelope) tool, using as boundaries the shoreline and the dune foot for each dataset. Additionally a DGPS-RTK survey of the dunes and beach was performed on 25/04/2004. Out of the 66 transects used for DSAS analysis, 10 were selected where the highest beach erosion was observed and used for projection of coastal retreat up to 2050, assuming a linear trend in the erosion tendency and no climatic-induced changes, no changes in sediment input to the area and no changes induced by man.

\section{Result and discussion}

From the analysis on shoreline change from aerial photos it emerged that during the period 1955-2007 the northern and central part of the bay experienced shoreline retreat, 
Côtes méditerranéennes menacées :

Risques et défis dans le contexte du changement climatique

while the southern bay advanced (Fig. 2). The northern section adjacent to the Torre Sveva headland retreated at a rate of $1 \mathrm{~m} /$ year, and the beach width from $80 \mathrm{~m}$ became only 20 wide. Shoreline retreat rates in the central portion of the area (Punta d'Isola) were accompanied by dune foot retreat with inland migration of the system and decrease of beach width from 80 to $30 \mathrm{~m}$.
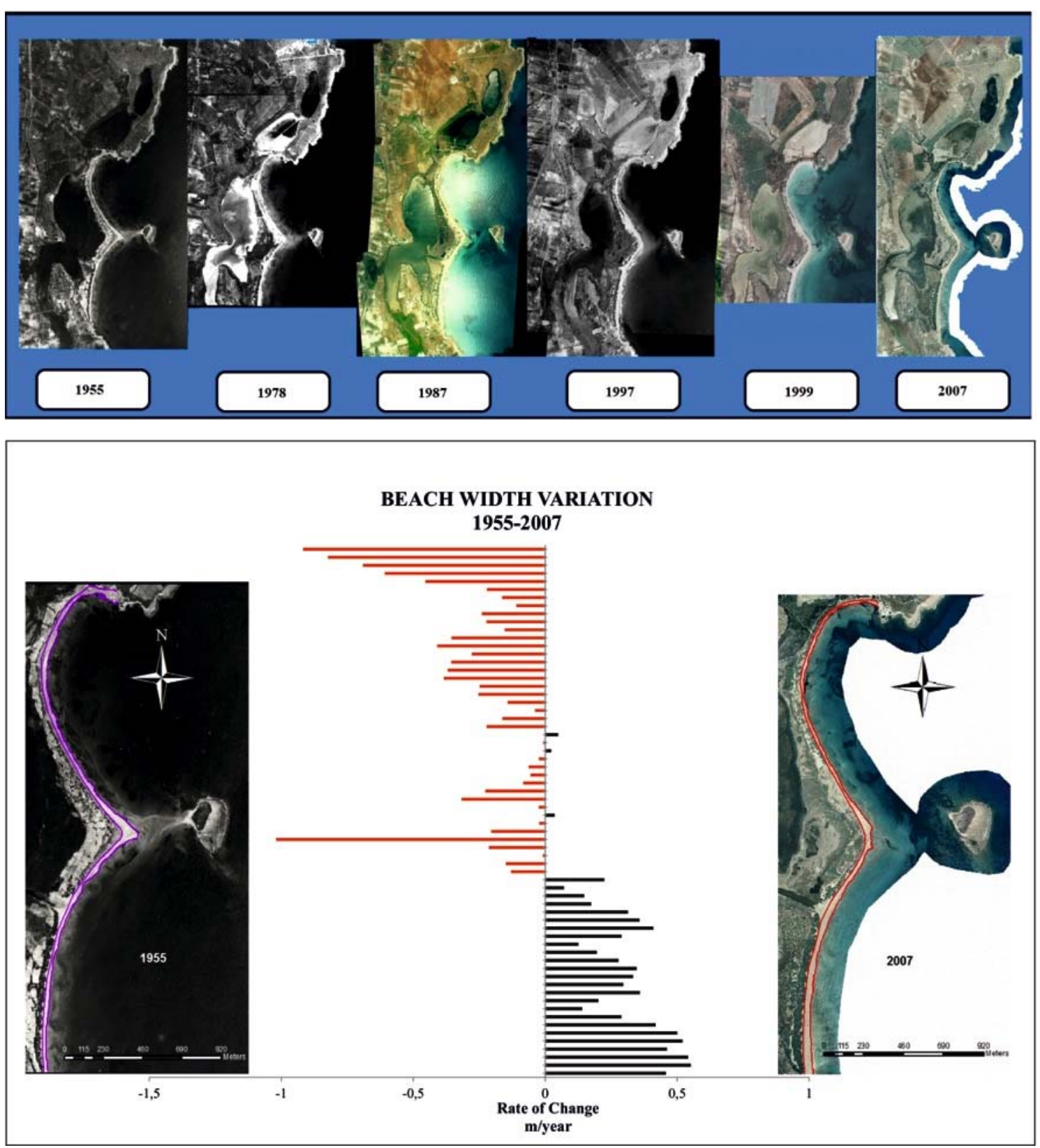

Figure 2. Shoreline changes observed at Vendicari in the period 1955-2007. 
Considering that this system receives almost no supply of fluvial sediments (GEREMIA, 2004), if only some mud fraction that fills the lakes, it could be a sign of a decreased sediment budget from in-situ biogenic sources. Here the sediment budget is in large part controlled by in-situ productivity, given the large bio-clastic carbonate component. Recent work on Sardinian beaches (DE FALCO et al., 2008) found an intrinsic relationship between the health of Posidonia meadows and availability of sand size carbonate fractions. As the bed in front of the system is occupied by Posidonia, this sand reduction may be considered an indicator of a suffering state for the meadow that may have started in that period. Linear extrapolation of retreat to 2050 predicts that in the northern part of the bay, near the Torre Sveva headland, the shoreline will be at the edge of the water lakes. The same trend is observed for Punta d'Isola. To notice that this is not including any sea level rise impact, which according to CIAVOLA et al. (2005) for a scenario up to 2050 would cause $10 \mathrm{~m}$ retreat, which have to be added to the $40-60$ $\mathrm{m}$, predicted here.

Finally, the photointerpretation identified a large overwash event in the central part of the area, already in the 1955 image, which was not identified in previous studies such as CIAVOLA et al. (2005). In the same area the large area mined by man in the 1970s has left a low elevation backshore, which is prone to be overwashed during storm events. Finally, the mapping of the edge of the lakes did not find considerable differences.

\section{Conclusions}

In conclusion, the coastal lakes of Vendicari have so far maintained their characteristics because have not yet been affected by morphological changes already underway on the beach. After the disappearance in the 1950s of the tombolo in front of the Vendicari Island, that divided the beach into two separate sections, the beach did not found a sediment balance, showing in the northern and central sections heavy erosion. This produced a greater risk of breakthrough of the dune ridge, also in view of the fact that in this area the dunes have low elevation. To notice that for the sectors adjacent to the Torre Sveva headland once that the shoreline is well behind it the retreat may slow down because of the sheltering of the headland.

In the south, the tendency of the emerged beach is opposite, showing in the period 1955-2007 advancement. Here there were no overwash processes observed, because these areas are protected by stable dune ridges, high and with dense vegetation.

Considering the future development of the shoreline up to 2050, the beach of the northern part of the system will migrate inward, invading the areas occupied the lake edges, causing the destruction of habitats of great importance at national and international level. If the managing Authority will decide to take into account these trends, it could run a program of low-impact interventions, such as a possible reconstruction of the dune belt where not present. However, a second option could be 
Côtes méditerranéennes menacées :

Risques et défis dans le contexte du changement climatique

considered, e.g. no intervention, thus accepting a possible creation of break point of the barrier.

\section{References}

APAT, Dipartimento Tutela delle Acque Interne e Marine - Servizio Difesa delle Coste (2006). Atlante Delle Coste "Il moto ondoso a largo delle coste italiane". URL: http://www.isprambiente.gov.it/it/servizi-per-lambiente/stato-delle-coste/atlante-delle-coste

CIAVOLA P., BALOUIN Y., GEREMIA F., ARMAROLI C. (2005). The back-barrier wetland system of Vendicari (SR):prediction of dune overwashing using shoreline variability indicators. UNESCO-ROSTE International Conference: Lagoons and Coastal Wetlands in the Global Change Context - Impacts and Management issues (Venice, April 2004), UNESCO proceedings series, 10 p.

DE FALCO G., BAROLI M., CUCCO A., SIMEONE S. (2008). Intrabasinal conditions promoting the development of a biogenic carbonate sedimentary facies associated with the seagrass Posidonia oceanica. Continental Shelf Research, Vol. 28(6), pp 797-812. http://dx.doi.org/10.1016/j.csr.2007.12.014

DOLAN R., HAYDEN B.P., MAY P., MAY S. (1980). The reliability of shoreline change measurements from aerial photographs. Shore and Beach, Vol. 48(4), pp 22-29. GEREMIA F. (2000). Evoluzione morfologica e dinamica sedimentaria dei "Pantani di Vendicari" (Sicilia Sudorientale). Tesi di dottorato in Scienze Ambientali (Ambiente marino e risorse), Università di Catania.

GRACIA F.J., GEREMIA F., PRIVITERA S., AMORE C. (2014). The Probable Karst Origin And Evolution Of The Vendicari Coastal Lake System (Se Sicily, Italy) Verjetni Kraški Izvor In Razvoj Obalnega Jeserskega Sistema Vendicari (Jv Sicilija, Italija). Acta Carsologica, Vol. 43(2-3), pp 215-228.

MOORE L.J. (2000). Shoreline mapping techniques. Journal of Coastal Research, Vol. 16(1), pp 111-124. URL : http://www.jstor.org/stable/4300016

THIELER E.R., HIMMELSTOSS E.A., ZICHICHI, J.L., AND ERGUL, AYHAN, (2009). Digital Shoreline Analysis System (DSAS) version 4.0 - An ArcGIS extension for calculating shoreline change: U.S. Geological Survey Open-File Report 2008-1278. *current version 4.3.

TSIMPLIS M.N. (1994). Tidal oscillations in the Aegean and Ionian Seas. Estuarine, Coastal and Shelf Science, Vol. 39(2), pp 201-208. http://dx.doi.org/10.1006/ecss.1994.1058 